Bačlija, Gologranc, Kukovič

Institucionalna kapaciteta regionalnih razvojnih agencij v Sloveniji?

Strokovni članek

\title{
Institucionalna kapaciteta regionalnih razvojnih agencij v Sloveniji
}

\author{
UDK: 353(497.4):001.892 \\ Irena Bačlija \\ Fakulteta za družbene vede, Univerza v Ljubljani \\ irena.baclija@fdv.uni-lj.si \\ Gaja Gologranc \\ gajagologranc@yahoo.com \\ Simona Kukovič \\ simona.kukovic@gmail.com
}

\begin{abstract}
IZVLEČEK
Ustava Republike Slovenije zagotavlja prebivalcem pravico do lokalne samouprave, ki jo uresničujejo $v$ občinah in (jih bomo) v pokrajinah. Kako nujna je vzpostavitev regionalne ravni je stvar razprave, zakonodajne aktivnosti $v$ preteklih letih pa kažejo, da o regionalizaciji ne bi smeli več dvomiti - negotov je le še čas ustanovitve pokrajin. V vmesnem obdobju med ustanovitvijo občin (1994) in ustanovitvijo pokrajin se je v Sloveniji poskušalo premostiti pomanjkljivosti druge ravni lokalne samouprave $z$ več mehanizmi in eden izmed njih je bila ustanovitev regionalnih razvojnih agencij. $\mathbf{V}$ članku zagovarjamo, da so imele regionalne razvojne agencije pomembno vlogo pri neformalnem združevanju lokalnih interesov in $v$ oblikovanju predregionalnih mrež sodelovanja ter usklajevanja potreb. $v$ skladu s tem smo izvedli raziskavo o kadrovskem in finančnem potencialu agencij ter o problematikah, s katerimi se srečujejo. Na podlagi dobljenih rezultatov smo poskusili pojasniti, kakšna bo vloga regionalnih razvojnih agencij po ustanovitvi pokrajin v Sloveniji ter odgovoriti na vprašanje ali se bo njihov kadrovski in infrastrukturni potencial pretočil v pokrajinsko upravo.
\end{abstract}

Ključne besede: regionalne razvojne agencije, skladni regionalni razvoj, pokrajine, zveza občin, regionalni razvojni svet,

JEL: Regional development policy (R 58)

Uprava, letnik VII, 1/2009 
Bačlija, Gologranc, Kukovič

Institucionalna kapaciteta regionalnih

razvojnih agencij v Sloveniji?

\section{Predvideno nagibanje $k$ regionalizaciji v Sloveniji}

Razprava o regionalizaciji v Sloveniji je tesno povezana z uresničevanjem načela subsidiarnosti, s skladnim regionalnim razvojem in z evropskimi trendi regionalizacije nasploh. Preden se vprašamo o primernosti procesa regionalizacije $\vee$ Sloveniji, ne moremo mimo dejstva, da je regionalni razvoj kot dejavnost usmerjanja gospodarskega, socialnega, prostorskega, infrastrukturnega, kulturnega in drugega razvoja neke države, proces, ki naj bi imel pozitivne sinergijske učinke na učinkovitost in skladnost razvoja narodnega gospodarstva države kot celote in njenih posameznih (regionalnih) delov (Ribičič, 1998, str. 52-53). Regionalizacijo kot pojem razumemo v institucionalnem smislu in je ne moremo enačiti z regionalizmom, ki je politično in ideološko gibanje. Obstajajo trije različni tipi regionalizacije: regionalizacija brez ustvarjene regionalne ravni, regionalna decentralizacija in politična regionalizacija (ali institucionalni regionalizem). Vsak od teh tipov ustreza različnim koncepcijam regije, vendar lahko različne oblike regij soobstajajo tudi znotraj ene države (Ribičič, 1998, str. 98). Regionalna decentralizacija je vpeljava nove lokalne oblasti na regionalni ravni. Pri tem regija nima višjega pravnega okvira od obstoječih lokalnih skupnosti, temveč ima širši geografski okvir. Njene naloge so $v$ glavnem gospodarske narave. Takšna narave regije se sklada z ustavnim sistemom unitarne države, pri čemer je regija teritorialna oblast, ki nima ustavnega jamstva za svoj obstoj. Politična regionalizacija pa pokriva široko lestvico, ki jo je $\vee$ Evropi najpopolneje uvedla Španija. Sedemnajst avtonomnih regionalnih skupnosti je $\vee$ Španiji politično samoupravnih tako, da njihov ustavni položaj uveljavlja njihovo organizacijo in pristojnosti znotraj okvirov, ki jih določa ustava (Ribičič, 1998, str. 99).

Bugarič (Ribičič, 1998, str. 121) prepoznava oba najpogosteje uporabljena argumenta $\vee$ podporo regionalizmu; politično-participativni in kulturnozgodovinski argument. Prvi poudarja politične prednosti decentralizirano upravljane družbe, drugi pa izhaja iz pomembnosti globljih kulturno-zgodovinskih vezi, ki naj bi povezovale in združevale prebivalce različnih regij $\vee$ državi. Eden najbolj utemeljenih razlogov $\vee$ prid regionalizaciji Slovenije je gotovo dejstvo, da so se po sprejetju nove slovenske ustave razvojne razlike med slovenskimi pokrajinami še dodatno poglobile. Močno nadpovprečno rast in hiter razvoj kaže osrednja regija z Ljubljano kot glavnim mestom; tej regiji do neke mere sledijo še obalno območje ter nekateri regionalni centri. Sloveniji grozijo velike razlike $v$ stopnji razvoja in kakovosti življenja prebivalcev $v$ njenih različnih delih, ki bodo po eni strani poglabljale razlike med regijami, po drugi strani pa krepile odpor 
Bačlija, Gologranc, Kukovič

Institucionalna kapaciteta regionalnih razvojnih agencij v Sloveniji?

do njenega središča. Kljub vsesplošnemu konsenzu v slovenskem političnem in strokovnem prostoru o neobhodnosti uvedbe pokrajin se $v$ okviru tega prispevka sprašujemo ali ni »umetna « regionalizacija slabša od tistega spontanega oblikovanja regionalnih enot, do katerega bi s potrpežljivim spodbujanjem združevanja občin, občinskih javnih služb in nenazadnje z opazovanjem organskega mreženja regionalnih razvojnih agencij (od tu naprej RRA) prej ali slej spontano prišlo.

Slovenija namreč spada $v$ sklop držav, ki imajo glede na demografske značilnosti in institucionalni razvoj manjšo potrebo po decentralizaciji (glej Dunn in Wetzel, 2000). Naklonjenost k decentralizaciji (regionalizaciji) naj bi bila tako $v$ pozitivni korelaciji z institucionalnim razvojem $\vee$ državi. Višja kot je $v$ neki državi legitimnost oblasti in višji kot je nivo liberalizacije, večja naj bi bila naklonjenost k decentraliziranemu izvajanju javnih storitev. Enako načelo se lahko uporabi tudi za drugi kriterij; decentralizacija bi morala biti $v$ pozitivni korelaciji z velikostjo in številom prebivalcev $v$ državi. Večja kot je država in več kot ima prebivalcev, bolj je naklonjena $k$ decentralizaciji. Slovenija $v$ skladu $s$ to teorijo spada med države $\mathrm{z}$ relativno močnim institucionalnim razvojem, vendar je zaradi svojih demografskih in teritorialnih značilnosti manj primerna oziroma manj naklonjena k decentralizaciji (glej tabelo 1).

Tabela 1: Predpostavljena potreba po decentralizaciji

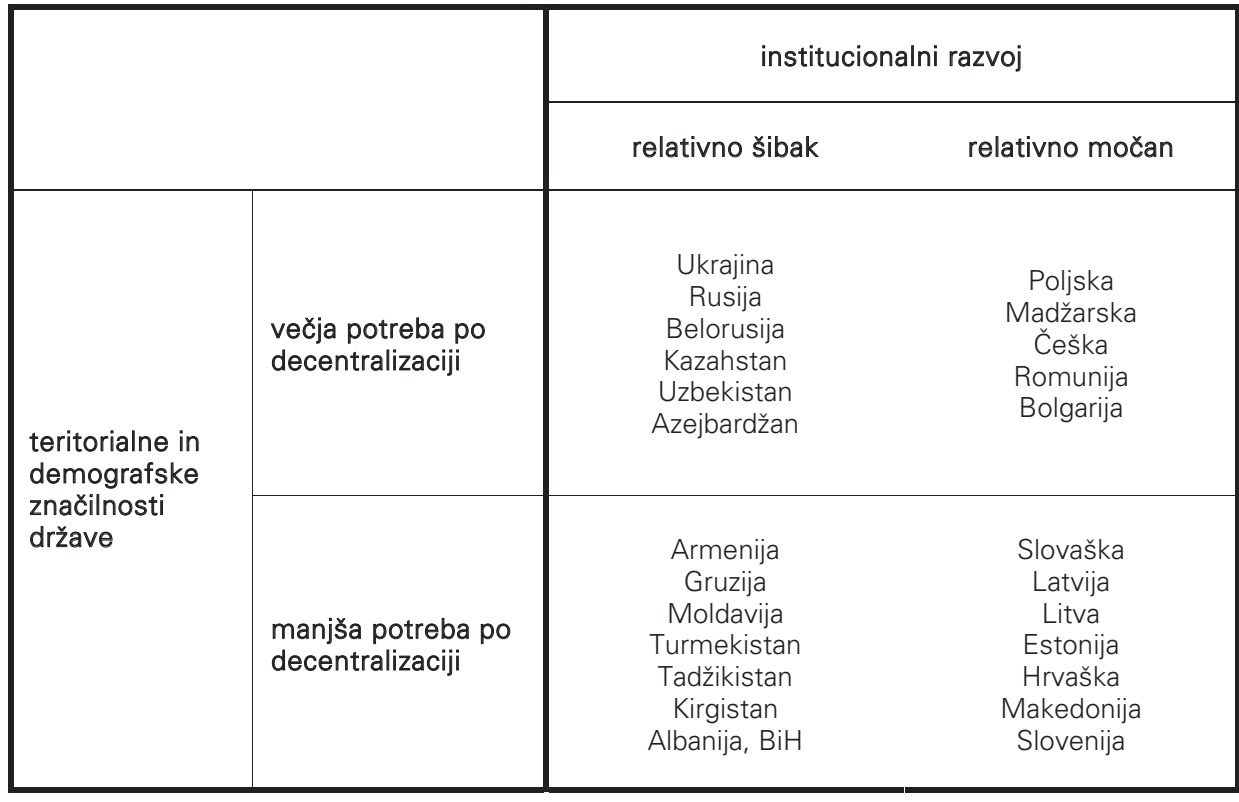

Vir: Dunn in Wetzel (2000, str. 6) 
Bačlija, Gologranc, Kukovič

\section{Institucionalna kapaciteta regionalnih \\ razvojnih agencij v Sloveniji?}

Haček (2002) po drugi strani išče širše vzroke za regionalizacijo v Sloveniji. Meni, da so pokrajine $v$ Sloveniji potrebne zaradi primerljivosti z državami Evropske unije in dodatnih možnosti prenosa sredstev za skladnejši regionalni razvoj. $V$ zahodni Evropi se je po drugi svetovni vojni uveljavljalo več oblik regionalnega razvoja, $v$ osemdesetih letih se je začel uveljavljati prenovljen model skladnejšega regionalnega razvoja, razvoja "od spodaj navzgor «. Politika Evropske unije je usmerjena $v$ krepitev razvojno nazadujočih regij; gre za podpiranje notranjega razvoja, ki izhaja iz razvojnih pobud lokalnih skupnosti. Poudarja se pomen regionalnih virov, ekološko sprejemljivega razvoja ter vključevanje domačega prebivalstva. Pri regionalni politiki Evropske unije gre za iskanje sožitja med procesi globalizacije in regionalizacije. ${ }^{\text {}}$

Pomemben razlog $v$ prid potrebi po takojšnji regionalizaciji Slovenije je tudi vedno večja stopnja centraliziranosti države. Reforma lokalne samouprave se je doslej namreč bolj ali manj ukvarjala z ustanavljanjem oziroma preoblikovanjem občin, kar se je $v$ praksi pokazalo $v$ tem, da smo iz nekaj nad 60 občin $\vee$ prvih letih po osamosvojitvi prišli na današnjih 210 občin s težnjo po nadaljnjem povečevanju. Reforma je popolnoma zanemarila povezovanje na regionalni ravni. Ta napaka je bila po mnenju mnogih (glej na primer Ribičič, 1998; Šmidovnik, 1991; Vlaj, 1998) zgolj logična posledica ustavne zasnove pokrajine, kot širše samoupravne lokalne skupnosti, ki je bila zgolj izpeljanka iz občine.

\subsection{Regionalna politika v Sloveniji}

Motivi za regionalno politiko so dvojni; lahko so (1) ekonomski - s pomočjo regionalne politike se doseže rast celotnega narodnega gospodarstva, saj sam tržni mehanizem ne vodi k optimalni porazdelitvi gospodarskih dejavnosti $v$ prostoru in posledica je nepopolna izkoriščenost produkcijskih faktorjev, predvsem dela; ali (2) družbeno-politični - cilj regionalne politike $v$ državi, ki si je kot pomemben cilj postavila socialno pravičnost, je odpravljanje medregionalnih razlik in doseganje približno enakih življenjskih pogojev za vse, kar tudi krepi pripadnost državi; torej je to pomembno politično in socialno vprašanje (Špes, 2000, str. 88). Medtem ko tradicionalna regionalna politika postavlja $\vee$ ospredje

\footnotetext{
1 Okvirno je ureditev lokalne samouprave zajeta $v$ Mednarodni evropski listini o lokalni samoupravi - MELLS (MELLS je Republika Slovenija podpisala 11. oktobra 1994 v Strasbourgu, državni zbor pa jo je ratificiral 1. oktobra 1996; začela je veljati 31. marca 1997), ki pa se regionalne ureditve le dotika. $V$ javnosti prevladuje mnenje, da MELLS v svojih členih eksplicitno navaja regionalizacijo kot izhodišče, ki naj bi mu države članice sledile, vendar temu ni tako. Večja dopolnila lahko pričakujemo $v$ Mednarodni evropski listini o regionalni samoupravi, ki pa je še $v$ fazi osnutka.
} 


\section{Bačlija, Gologranc, Kukovič \\ Institucionalna kapaciteta regionalnih razvojnih agencij v Sloveniji?}

razvoj šibkih območij zaradi pomanjkanja kapitala in kvalificirane delovne sile, sodobni pristopi poudarjajo predvsem pomanjkanje podjetniške iniciative, inovacij, specifičnega znanja in medregionalnih in mednarodnih povezav ter slabše razvito infrastrukturo. $V$ prejšnjem Zakonu o spodbujanju skladnega regionalnega razvoja (Ur. I. RS, št. 60/99 in 56/03) (v nadaljevanju prejšnji zakon) je bila regionalna razvojna politika precej razvojno naravnana in opredeljena kot regionalna strukturna politika, ki je sklop razvojnih aktivnosti, programov in ukrepov države, lokalnih skupnosti in drugih nosilcev organiziranih interesov na regionalni ravni za doseganje razvojnih ciljev ob upoštevanju skladnega regionalnega razvoja.

Sicer ima spodbujanje skladnega regionalnega razvoja $v$ Sloveniji korenine še $v$ letu 1971, ko je bil sprejet prvi pravni akt, ki je določal naloge s področja regionalne politike, vendar se je zadnja večja sprememba zgodila leta 1999, ko je bil za spodbujanje razvoja demografsko ogroženih območij sprejet že omenjeni Zakon o spodbujanju skladnega regionalnega razvoja. Zaradi pogostih kritik (povezanih predvsem z določili o organizaciji in izvajanju regionalne politike) je državni zbor sprejel nov Zakon o spodbujanju skladnega regionalnega razvoja (Ur. I. RS, št. 93/2005) (v nadaljevanju zakon). Prejšnji zakon je bil vsebinsko spremenjen $v$ tolikšni meri, da ni bilo mogoče vnesti le popravkov zakona temveč je bilo treba oblikovati nov zakon. Za namen našega članka je najpomembnejša tista vnesena sprememba, ki se nanaša na izvajanje in sprejemanje regionalne politike. $Z$ novim zakonom se vnašajo spremembe $v$ organizacijo razvoja oziroma njenih nosilcev. $\vee$ vsaki razvojni regiji ${ }^{2}$ se bo po novem ustanovila zveza občin, katere naloge bodo sprejemanje regionalnega razvojnega programa in potrjevanje izvedbenega načrta regionalnega razvojnega programa.

Pred tem je priprava regionalnega razvojnega programa $^{\mathbf{3}}$ na podlagi Pravilnika o organizaciji in pogojih za opravljanje nalog regionalne razvojne agencije (Ur. I. RS, št. 110/2004) sodila $\vee$ delokrog nalog regionalnih razvojnih agencij (RRA), iz novega zakona pa ni nedvoumno razvidno, kdo pripravi regionalni razvojni

2 Razvojne regije so prostorsko identične statističnim regijam na 3. ravni SKTE (standardna klasifikacija teritorialnih enot). Klasifikacijo SKTE je razvila Evropska unija; gre za sistemizacijo, ki naj bi zagotovila večjo preglednost med različnimi stopnjami držav članic. Klasifikacija ima 4 ravni. V SKTE 1 spadajo velike države članice Evropske unije (kriterij je število prebivalstva); v SKTE 2 spadajo manjše države članice in večje regije; v SKTE 3 večje upravne enote in $v$ SKTE 4 manjše upravne enote $v$ državi.

3 "Regionalni razvojni program « je temeljni programski dokument na regionalni ravni, ki opredeljuje razvojne prednosti razvojne regije, določi razvojne prioritete regije in vsebuje finančno ovrednotene programe spodbujanja razvoja v razvojni regiji (5. člen, ZSRR-1). 
Bačlija, Gologranc, Kukovič

Institucionalna kapaciteta regionalnih

razvojnih agencij v Sloveniji?

program, temveč le kdo ga sprejme. Tako je stari zakon ( $v$ 11. členu ${ }^{4}$ ) predvideval prenos vodenja in priprave regionalnega razvoja iz občin na RRA, kar pomeni, da je bil levji del odločanja in izvajanja poverjen strokovno-tehničnim službam RRA. RRA so imele z zainteresiranimi občinami sklenjene pogodbe o sodelovanju, na podlagi katerih so pri izvajanju razvojne regionalne politike imele relativno proste roke. $V$ primeru, da občine niso ustanovile RRA in je bila priprava regionalnega razvojnega programa določena s strategijo regionalnega razvoja Slovenije, je na podlagi starega zakona njegovo pripravo vodila Javna agencija za regionalni razvoj. Po starem zakonu so bili nosilci regionalne strukturne politike Svet za strukturno politiko, Javna agencija za regionalni razvoj, Sklad za regionalni razvoj in ohranjanje poseljenosti slovenskega podeželja in RRA. Poleg tega so bili nosilci regionalne strukturne politike tudi ministrstva, ki so dodeljevala spodbude, pomembne za regionalni razvoj. Zaradi procesa regionalizacije, ki v postopku oblikovanja pokrajin $\vee$ Sloveniji predvideva, da bodo imele pokrajine status lokalno-samoupravnih skupnosti, pa je treba $\vee$ proces odločanja in vodenja vključiti tudi politična telesa.

Po novem zakonu namreč občine na ravni razvojne regije ustanovijo zvezo občin, katere naloge so med drugim sprejemanje regionalnega razvojnega programa in potrjevanje izvedbenega načrta regionalnega razvojnega programa. Organ odločanja zveze občin je svet regije, ki ga sestavljajo župani občin ustanoviteljic ter z aktom o ustanovitvi zveze določeno število predstavnikov občinskih svetov občin ustanoviteljic. Vsaka od ustanoviteljic mora imeti vsaj dva člana sveta in nobena ne more imeti več kot polovice članov sveta. Z aktom o ustanovitvi zveze se $v$ okviru nalog, ki jih opravljajo občine $\vee$ zvezi, določijo predpisi in drugi akti iz pristojnosti občinskih organov, za katerih sprejemanje bo po ustanovitvi zveze občin pristojen svet zveze. Naloge RRA je podrobneje določal pravilnik, ki je bil hierarhično nad navodilom, ki je določal naloge sveta regije in regionalnega razvojnega sveta. Po novem ZSRR-1 je ravno obratno: naloge sveta regije in regionalnega razvojnega sveta so natančneje določene s hierarhično višjim pravnim aktom kot naloge RRA (te so določene s pogodbo med svetom regije in posamezno RRA, kar posledično prinaša različne naloge RRA $v$ vsaki regiji). Svet regije prevzame vlogo povezovalca, koordinatorja in nadzornika razvoja $v$ regiji. Po novem ZSRR-1 so RRA omenjene "samo" kot strokovna, tehnična in administrativna podpora svetu regije in regionalnemu razvojnemu svetu ter kot institucija, ki naj bi $v$ regiji

4 11. člen ZSRR-UPB1 se glasi "Vodenje priprave regionalnega razvojnega programa občine poverijo regionalni razvojni agenciji iz 17. člena tega zakona«. 
Bačlija, Gologranc, Kukovič

Institucionalna kapaciteta regionalnih razvojnih agencij v Sloveniji?

opravljala splošne razvojno pospeševalne naloge. Vprašanje pa je, katere splošne razvojne pospeševalne naloge naj bi RRA po novem opravljale, saj jih ZSRR-1 nikjer jasno ne opredeljuje. Tako se predvideva, da se bo narava odločanja prenesla iz sfere regionalnih razvojnih strategij $\vee$ sfero regionalnega političnega odločanja in se bo moč odločanja $v$ večji meri prenesla na regionalne politične akterje. RRA, ki so bile $v$ starem zakonu eden izmed nosilcev regionalne strukturne politike, pa se opuščajo.

\section{Regionalne razvojne agencije}

Posledice reforme strukturne regionalne politike $\vee$ Sloveniji so bile poleg drugega tudi oblikovanje novih institucij na državni in lokalni ravni (Pečar, 2002, str. 15). Delovanje RRA je bilo okvirno določeno v starem Zakonu o spodbujanju skladnega regionalnega razvoja ${ }^{\mathbf{5}}$, ki je predvideval, da je RRA mogoče ustanavljati po potrebi (tam kjer se občine odločijo za oblikovanje ali ustanovitev RRA) in je opredeljeval okviren delokrog in omejitve RRA. Natančneje je delovanje RRA urejal Pravilnik o organizaciji in pogojih za opravljanje nalog regionalne razvojne agencije (Ur. I. RS 52/2000), ki pa od 7. 10. 2006 ne velja več.

Regionalne razvojne agencije so v okviru novega zakona omenjene, vendar nikakor več ne dosegajo svojih prejšnjih nalog in funkcij. Še naprej so zadolžene za pripravo regionalnega razvojnega programa in za pomoč pri pripravi regionalnih projektov, vendar bodo sedaj služile bolj kot tehnična in strokovna podpora prej omenjenima zvezi in svetu. Zaradi načela izvajanja celovitosti regionalne politike postane regionalna politika obveznost vseh nosilcev odločanja na vseh ravneh odločanja, kar je glede na pričakovani nastanek pokrajin v Sloveniji sicer smotrno, vendar hkrati odriva od procesa odločanja tiste subjekte spodbujanja razvoja na regionalni ravni, ki so $v$ tem procesu do sedaj aktivno sodelovali. Z nastankom pokrajin se bo tako odločanje o razvoju in skladnosti regionalne

5 Delovanje RRA je bilo v starem zakonu (ZSRR-UPB1) določeno v 17. členu, ki se je glasil: Za pripravo regionalnih razvojnih programov ter drugih dogovorjenih nalog s področja regionalne strukturne politike zlasti pri pospeševanju gospodarskega, socialnega, prostorskega in okoljskega razvoja lahko občine in osebe javnega in zasebnega prava ustanovijo regionalno razvojno agencijo.

Regionalna razvojna agencija lahko opravlja tudi izvajalske naloge s področja regionalne strukturne politike.

Občine se lahko za opravljanje nalog regionalne razvojne agencije pogodbeno dogovorijo z obstoječo gospodarsko družbo ali drugo organizacijo.

Podrobnejše pogoje za opravljanje nalog regionalne razvojne agencije predpiše minister, pristojen za regionalni razvoj. 
Bačlija, Gologranc, Kukovič

\section{Institucionalna kapaciteta regionalnih razvojnih agencij v Sloveniji?}

politike preneslo iz strokovno-tehničnih služb v pristojnost občinskega oziroma pokrajinskega političnega odločanja. Ker naj bi pokrajine postale funkcionalne ozemeljske enote za usklajevanje trajnostnega razvoja in izvajalke ter kreatorke regionalne razvojne politike, je smiselno, da oblikujejo in sprejemajo razvojne programe. Do sedaj so regionalne razvojne programe (na podlagi 3. člena Pravilnika o organizaciji in pogojih za opravljanje nalog regionalne razvojne agencije; Ur. I. št. 110/2004) pripravljale regionalne razvojne agencije. Glede na predloge vsebinskih razmejitev po resorjih razlaga Služba vlade RS za lokalno samoupravo in regionalno politiko (2007), da bo dosedanji organizacijski model oblikovanja in sprejemanja regionalnih razvojnih programov, ki je temeljil na povezovanju občin, nadgrajen tako, da bodo pokrajinski organi z načrtovanjem razvoja celotnega območja pokrajine oblikovali politične cilje regionalnega razvoja. Sedanjo vlogo regionalnih razvojnih agencij pa naj bi prevzele pokrajinske uprave, kar pa ni nujen razplet dogodkov $v$ vseh pokrajinah. O tem bodo namreč odločale pokrajine skupaj z občinami, kot ustanoviteljicami teh subjektov. Nekatere regionalne razvojne agencije imajo statusno obliko zasebnih podjetij, za katera ni mogoče predpostaviti, da bodo enostavno prešla v pokrajinske uprave. $V$ takšnih primerih je bolj verjetno, da bodo zasebne regionalne razvojne institucije poiskale svoje poslovne priložnosti na trgu in $\vee$ tem okviru morda tudi še opravljale določene naloge za pokrajinske uprave na podlagi pogodbe. Tudi o tem naj bi odločila pokrajina (ibidem).

Novi zakon $\vee$ 76. členu ${ }^{\boldsymbol{6}}$ tako predvideva kakšno bo delovanje RRA v prehodnem obdobju (do ustanovitve subjektov iz 29. člena zakona). V tem obdobju bodo RRA nadaljevale z izvajanjem nalog spodbujanja regionalnega razvoja na regionalni

6 76. člen se glasi:

(1) Za izvajanje splošnih razvojno pospeševalnih nalog v regiji in zagotavljanje strokovne, tehnične in administrativne podpore za delovanje sveta regije in regionalnega razvojnega sveta ustanovijo zveza ali občine zavod ali drugo pravno organizacijsko obliko. Medsebojna razmerja med zvezo ali občinami ter subjektom iz prejšnjega stavka se določijo s pogodbo. (2) Organ, pristojen za regionalni razvoj, vodi evidenco subjektov iz prejšnjega odstavka. (3) Minister, pristojen za regionalni razvoj, s podzakonskim predpisom določi način vodenja evidence subjektov iz prvega odstavka tega člena, minimalne pogoje za opravljanje nalog subjekta iz prvega odstavka tega člena in obvezne elemente akta o ustanovitvi subjekta iz prvega odstavka tega člena ter pogodbe o izvajanju njegovih nalog, ki so v javnem interesu. 7 29. člen se glasi:

(1) Za izvajanje splošnih razvojno pospeševalnih nalog v regiji in zagotavljanje strokovne, tehnične in administrativne podpore za delovanje sveta regije in regionalnega razvojnega sveta ustanovijo zveza ali občine zavod ali drugo pravno organizacijsko obliko. Medsebojna razmerja med zvezo ali občinami ter subjektom iz prejšnjega stavka se določijo s pogodbo.

(2) Organ, pristojen za regionalni razvoj, vodi evidenco subjektov iz prejšnjega odstavka. (3) Minister, pristojen za regionalni razvoj, s podzakonskim predpisom določi način vodenja evidence subjektov iz prvega odstavka tega člena, minimalne pogoje za opravljanje nalog subjekta iz prvega odstavka tega člena in obvezne elemente akta o ustanovitvi subjekta iz prvega odstavka tega člena ter pogodbe o izvajanju njegovih nalog, ki so v javnem interesu. 
Bačlija, Gologranc, Kukovič

Institucionalna kapaciteta regionalnih razvojnih agencij v Sloveniji?

ravni. Lastniški deleži države in javnih skladov $\vee$ regionalnih razvojnih agencijah so se $v$ treh mesecih po uveljavitvi tega zakona prenesli $\vee$ občine $v$ razvojni regiji. Sicer je smiselno, da se z ustanovitvijo pokrajin prenese odločanje o strateškem razvoju na nosilce političnega odločanja, vendar je vprašljivo, v kolikšni meri so zakonodajalci upoštevali pretekle izkušnje nosilcev regionalne strukturne politike, še posebej RRA.

\subsection{Teritorialna pokritost Slovenije $z$ regionalnimi razvojnimi agencijami}

Prihodnost RRA je torej negotova, dejstvo pa je, da so RRA dolgoletno krojile regionalni razvoj $\vee$ Sloveniji in ob tem pridobivale dragocene izkušnje ter razvijale institucionalno kapaciteto. Da bi lažje razumeli njihovo vlogo in potencial smo spomladi leta $2007^{\boldsymbol{s}}$ izvedli empirično raziskavo, katere cilj je bil zajeti temeljne podatke o delovanju (finance, kadri, teritorialna pokritost) ter o izkušnjah, ki so ga pridobile $v$ času svojega delovanja (problematike, sodelovanje z institucijami in podobno).

$\checkmark$ empirično analizo smo zajeli samo RRA, ki so bile vpisane $v$ register Agencije Republike Slovenije za regionalni razvoj in so imele zakonsko določen status. Te so: RRA Mura, RRA Notranjsko-kraške regije, BSC Poslovno podporni center Kranj, Posoški razvojni center, RRA Koroška, RRA Posavje, Regionalni center za razvoj Zasavje, Regionalni razvojni center Koper, RRA Celje, Regionalni center Novo Mesto, RRA Ljubljanske urbane regije in Mariborska razvojna agencija. Če pogledamo statistične regije, lahko ugotovimo, da se področje posameznih RRA $v$ veliki meri ujema z mejami statističnih regij ter $\mathrm{s}$ predlaganimi območji prihodnjih štirinajstih pokrajin $\vee$ Sloveniji. $\vee$ evidenco pri Agenciji Republike Slovenije za regionalni razvoj je bilo vpisanih dvanajst RRA. Poleg omenjenih RRA so na posameznih območjih delovale še območne regionalne agencije in številne druge razvojne institucije, ki nimajo zakonsko določenega statusa in tako nimajo možnosti sodelovanja pri pripravi dokumentov razvojnega načrtovanja.

8 Raziskavo smo opravili na Fakullteti za družbene vede, v okviru predmeta Primerjalni federalizem in regionalizem. Anketirali smo predstavnike vseh 12 RRA, ki so bile vpisane v evidenco pri Agenciji Republike Slovenije za regionalni razvoj. Anketni vprašalniki so bili standardizirani, sestavljeni pa so bili iz treh tematskih sklopov, in sicer (a) osnovni podatki o RRA, (b) sodelovanje RRA z ostalimi institucijami in (c) področja delovanja RRA. 
Bačlija, Gologranc, Kukovič

\section{Institucionalna kapaciteta regionalnih \\ razvojnih agencij v Sloveniji?}

\section{Slika 1: Pokritosti z regionalnimi razvojnimi agencijami}

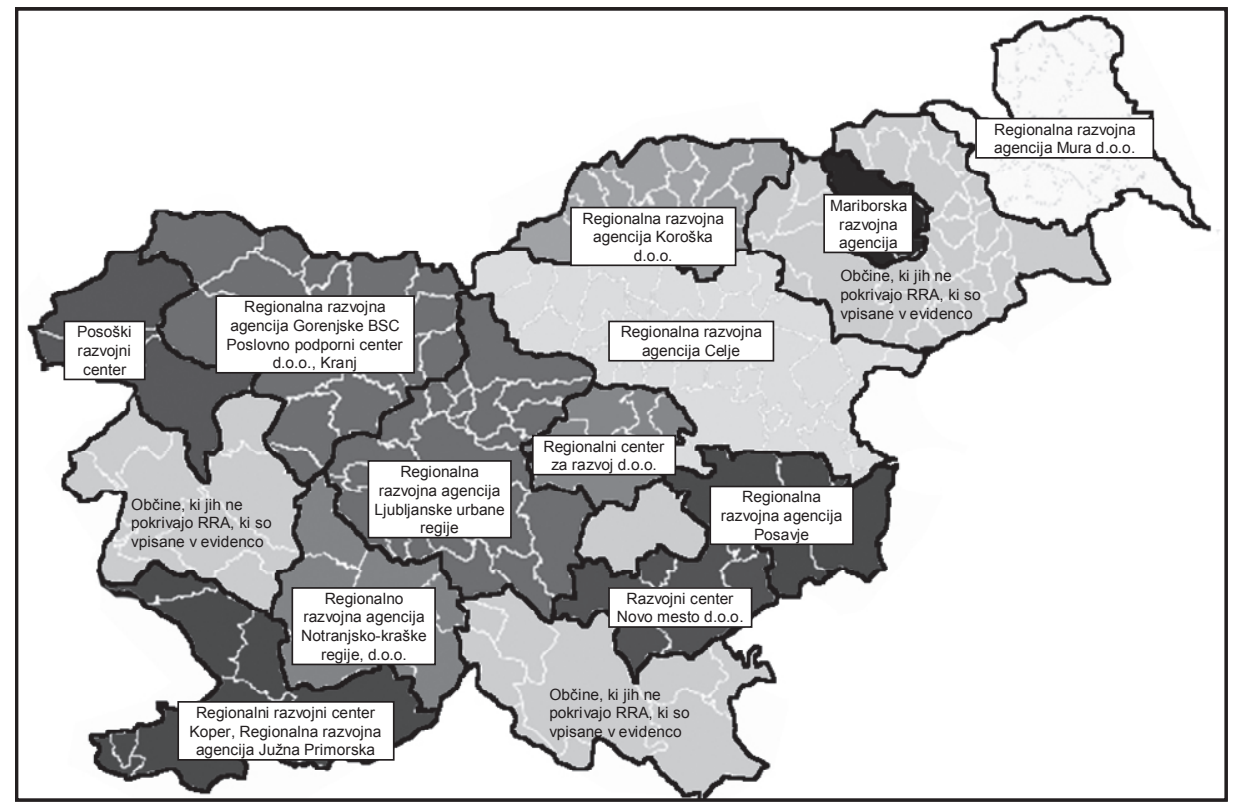

Delovanje RRA je (bilo) določeno v pravilniku. V nadaljevanju navajamo Pravilnik o organizaciji in pogojih za opravljanje nalog RRA (od tu naprej pravilnik) iz leta 2000 (Ur. I. RS, št. 52/2000). Pravilnik je bil leta 2004 spremenjen in dopolnjen (Ur. I. RS, št. 110/2004), 7. oktobra 2006 pa je prenehal veljati, kot smo navedli že v uvodu. Od takrat je v veljavi nov Pravilnik o subjektih spodbujanja razvoja na regionalni ravni (Ur. I. RS, št. 103/2006; v nadaljevanju novi pravilnik). Pravilnik je v svojem 2. členu navajal, da RRA opravljajo razvojne naloge za območje ene ali več statističnih regij. Za opravljanje nalog so jih pooblastile sodelujoče občine, pri izvajanju le-teh so se RRA lahko povezovale v mrežo razvojnih institucij z območnimi agencijami, ki so delovale na funkcionalno-interesno zaključenih območjih. Novi pravilnik prav tako $\vee 2$. členu natančneje predpisuje, da se $\vee$ evidenco pri službi ${ }^{\mathbf{9}}$ lahko vpiše le en subjekt iz vsake razvojne regije. Torej teritorialna razporeditev RRA lahko prikazuje, da so regije dejansko zasnovane glede na skupne socio-geografske elemente, preko katerih se povezujejo.

Peti člen pravilnika je pojasnjeval, da mora RRA ustanoviti večina občin na območju statistične regije oziroma ji dati pooblastilo za pripravo regionalnega razvojnega programa in za opravljanje razvojnih nalog. Pri opazovanju pokritosti z RRA se pokaže zanimivost: nekatere občine so nastopile $v$ vlogi soustanoviteljice

9 Služba Vlade Republike Slovenije za lokalno samoupravo in regionalno politiko. 
Bačlija, Gologranc, Kukovič

Institucionalna kapaciteta regionalnih

razvojnih agencij v Sloveniji?

več RRA. Tako je bila na primer občina Radeče soustanoviteljica Regionalnega centra za razvoj Zasavje in RRA Celje; občina Logatec soustanoviteljica RRA Ljubljanske urbane regije in RRA Notranjsko-kraške regije; občina Šmartno pri Litiji in občina Litija pa RRA Ljubljanske urbane regije in Regionalnega centra za razvoj Zasavje. Po drugi strani lahko ugotovimo, da so bile Podravska, Goriška in Jugozahodna pokrajina le delno "zastopane«. Na teh območjih so delovale (in ponekod še delujejo) druge razvojne institucije (npr. Center za pospeševanje podjetništva Piran, Razvojna agencija ROD Ajdovščina...), ki (še) nimajo zakonsko določenega statusa, torej niso bile vpisane v evidenco pri Agenciji Republike Slovenije za regionalni razvoj. Po našem mnenju je prihajalo do teh razlik zaradi specifičnosti posamezne občine. Občine, ki so bile soustanoviteljice več RRA, so bolj odprte, zainteresirane za sodelovanje in povezovanje. Prav tako so bile te občine pripravljene financirati RRA ter izvajati skupne (regionalne) projekte in ne samo na območju občine. Občine, ki niso bile soustanoviteljice nobene RRA, kljub možnostim očitno niso imele potrebe, da bi se povezovale oziroma so se povezovale z drugimi institucijami. Vsekakor menimo, da so občine, ki so bile soustanoviteljice RRA in so z njimi sodelovale ter se povezovale, pridobile izkušnje, ki jim bodo koristile tudi po ustanovitvi pokrajin, saj se tudi tukaj predvideva povezovanje $v$ pokrajinskih svetih.

\subsection{Razvojni in kadrovski potencial regionalnih razvojnih agencij}

$V$ dvanajstih registriranih RRA je bilo zaposlenih 150 ljudi. Vendar so med RRA obstajale precejšne razlike $\vee$ številu zaposlenih, največ je bilo 23 in najmanj 7 zaposlenih. Glede na dobljene rezultate smo pričakovali, da ima RRA, ki jo je ustanovilo največ občin, tudi največ zaposlenih. Po pregledu podatkov smo ugotovili, da temu ni tako. Kot primer izpostavljamo Regionalni center za razvoj Zasavje, ki ga je ustanovilo samo šest občin, a je zaposloval kar 23 ljudi, medtem ko je imel RRA Celje 32 občin ustanoviteljic in samo 12 zaposlenih. Sklepamo torej, da število ustanoviteljic ne pogojuje števila zaposlenih $v$ posamezni RRA, ampak se to očitno navezuje na pridobljene finančne vire, ki omogočajo tolikšno število zaposlenih.

Glede izobrazbe zaposlenih je $\vee$ novem pravilniku $\vee$ tretjem členu navedeno, da mora subjekt redno zaposlovati ustrezno usposobljeno osebje za vodenje, administrativna opravila in opravljanje nalog na vsakem od vsebinskih področij dela. Zaposleni pokrivajo različna področja, razlikuje pa se tudi stopnja njihove izobrazbe. Dobljeni podatki kažejo, da ima največ zaposlenih (kar 58\%) 
Bačlija, Gologranc, Kukovič

Institucionalna kapaciteta regionalnih

razvojnih agencij v Sloveniji?

univerzitetno izobrazbo, sledijo zaposleni z višjo ali visokošolsko izobrazbo (15\%), s srednješolsko izobrazbo (13\%), ter z doseženo izobrazbo magisterija ali doktorata znanosti (13\%). Le 1\% je zaposlenih, ki imajo osnovnošolsko izobrazbo. Ugotovili smo, da imajo kadri znanja iz različnih področij (od pravnikov, politologov, ekonomistov, strojnikov, gradbenikov, itd.). Zanimalo nas je ali se RRA srečujejo s pomanjkanjem kadrov. $V$ petih RRA kadrovskega primanjkljaja niso zaznali, $v$ dveh bi potrebovali kadre $s$ področja prava, $v$ eni pa $s$ področja ekonomije. Preostale so izrazile potrebo po fleksibilnem in multidisciplinarnem kadru, ki bi imel organizacijske sposobnosti vodenja obsežnih projektov z najrazličnejših področij. Slednje je lahko nedvoumen indikator tudi za bodoče pokrajinske uprave, ki bodo $v$ nekaterih primerih prevzele naloge RRA; zaposlovanje visoko kakovostnega in multidisciplinarnega kadra bo odločilnega pomena.

To nam lahko pove, da (1) so RRA zaposlovale visoko izobražene kadre zaradi potrebe po strokovnem znanju, ki je potrebno za izpolnitev zahtevnih in obširnih nalog, (2) da je bile potrebna izobrazba različnih smeri, (3) da so bili zaposleni kljub svoji strokovnosti dovolj prilagodljivi pri osvajanju drugih področij delovanja RRA. Lahko trdimo, da je bil kadrovski potencial gonilna sila RRA.

\subsection{Sodelovanje RRA z drugimi institucijami}

RRA so pri izpolnjevanju svojih nalog in pri projektih (kot je navajal 7. člen pravilnika) sodelovale s Skladom za regionalni razvoj in ohranjanje poseljenosti slovenskega podeželja, z drugimi RRA, z Agencijo za kmetijske trge in razvoj podeželja, s Pospeševalnim centrom za razvoj malega gospodarstva ter z zbornicami in socialnimi partnerji. Ker nas je pri raziskovanju zanimalo, $v$ kolikšni meri in $s$ katerimi drugimi institucijami na evropski, nacionalni ter regionalni ravni so RRA dejansko sodelovale, smo $v$ vprašalniku zajeli tudi to tematiko. Dobljeni podatki kažejo, da so bile RRA $v$ stikih z različnimi institucijami. Vseh dvanajst RRA je namreč sodelovalo s slovenskimi upravnimi in političnimi institucijami ter z občinami. Sledilo je sodelovanje z zasebnimi podjetji in javnimi zavodi (enajst RRA). Z evropskimi institucijami jih je sodelovalo deset, prav toliko jih je izbralo ponujeni možni odgovor »drugo».

Podatek, da je vseh dvanajst RRA sodelovalo z občinami, smo preverili tudi pri občinah (glej tabelo 2). Vidimo, da občine sodelujejo z RRA, kot ustanoviteljice ali pa se preko RRA prijavljajo na projekte. Pozornost pa vzbudi odgovor, da so občine le redko sodelovale z RRA, saj naj ne bi poznale njihovega 
Bačlija, Gologranc, Kukovič

Institucionalna kapaciteta regionalnih razvojnih agencij v Sloveniji?

delovanja. To lahko pomeni, da (1) je $v$ občinah primanjkovalo zanimanje za pridobivanje podatkov o delovanju RRA ali (2) RRA niso bile dovolj prepoznavne v svojem lokalnem okolju.

Tabela 2: Sodelovanje občin z regionalnimi razvojnimi agencijami (možnih je več odgovorov) $\mathrm{N}=117$

\begin{tabular}{|c|c|c|}
\hline & DA & NE \\
\hline Občina je soustanovitelj & $101(86,3 \%)$ & $16(13,7 \%)$ \\
\hline Preko RRA se prijavljajo na projekte & $72(61,5 \%)$ & $45(38,5 \%)$ \\
\hline $\begin{array}{l}\text { Redko sodelujejo z RRA, ker ne poznajo } \\
\text { njihovega delovanja }\end{array}$ & $117(100 \%)$ & $0(0 \%)$ \\
\hline $\begin{array}{l}\text { Z RRA redko sodelujejo, ker ima slednja } \\
\text { neprimerne projekte }\end{array}$ & $6(5,1 \%)$ & $111(94,9 \%)$ \\
\hline Z RRA ne sodelujejo & $1(0,9 \%)$ & $116(99,1 \%)$ \\
\hline Drugo & $6(5,1 \%)$ & $111(94,9 \%)$ \\
\hline
\end{tabular}

Vir: Haček, Brezovšek, Bačlija, 2008.

Ugotovili smo, da je zanimanje za sodelovanje med občinami in RRA obstajalo. Sodelovale so, vendar očitno samo na tistih področjih in pri projektih, o katerih so imele občine zbranih dovolj informacij oziroma so jih dovolj dobro poznale. Projekti, ki so jih izvajale RRA, so bili po mnenju občin zelo primerni, saj je trditev o nesodelovanju občin z RRA zaradi neprimernih projektov zanikalo kar 111 občin. Glede na visoki odstotek RRA, ki so sodelovale z evropskimi institucijami ter zasebnimi podjetji in javnimi zavodi, lahko trdimo, da so 
Bačlija, Gologranc, Kukovič

Institucionalna kapaciteta regionalnih

razvojnih agencij v Sloveniji?

imele RRA dobro razvejano mrežo sodelovanja, ki je bila prav gotovo koristna za njihovo delovanje.

\subsection{Financiranje RRA}

Ker so RRA na vprašanje o problemih, ${ }^{10}$ s katerimi se srečujejo pri svojem delovanju $\vee$ največji meri izpostavile financiranje, poglejmo, kako je bilo financiranje RRA določeno $v$ Pravilniku ter kateri so bili viri financiranja pri posamezni RRA. V osmem členu pravilnika je bilo pojasnjeno, da se RRA, ki so vpisane $v$ evidenco, financirajo iz sredstev ustanoviteljev, sredstev državnega proračuna, sredstev za izvajanje projektov $\vee$ okviru programov državnih razvojnih spodbud, mednarodne pomoči in ostalih sredstev zainteresiranih naročnikov. Kot je še določeno, so lahko RRA pridobivale sredstva iz državnega proračuna s predložitvijo štiriletnega okvirnega programa dela in letnega podrobnega finančnega načrta. Pri naši raziskavi smo naštete vire financiranja ponudili kot možne odgovore in zaprosili anketirane, da nam nanje odgovorijo v odstotkih, glede na njihovo RRA (glej tabelo 3).

Kot je razvidno že na prvi pogled, se odstotki pridobljenih virov med posameznimi RRA močno razlikujejo. Devet RRA je odgovorilo, da se delno ( $v$ večjem ali manjšem deležu) financirajo iz sredstev za izvajanje projektov $v$ okviru programov državnih razvojnih spodbud. Osem RRA se je delno financiralo iz sredstev ustanoviteljev - tukaj lahko izpostavimo RRA Ljubljanske urbane regije s kar 80\%; Regionalni center za razvoj Zasavje in RRA Notranjsko-kraške regije pa se iz teh sredstev nista financirala. Kot tretji najpogostejši vir so navedli sredstva zainteresiranih naročnikov - sedem RRA. Najmanj RRA (štiri) pa so se financirale iz sredstev mednarodnih pomoči (izstopa Posoški razvojni center s kar 50\%). Kot »drugo « pa so najpogosteje zapisali, da so to sredstva iz izvajanih raznih projektov na trgu, izredni viri in razni razpisi. Tukaj izstopata RRA Koper (82\%) in RRA Notranjsko-kraške regije (80\%).

10 RRA so se pri svojem delovanju nemalokrat srečevale z različnimi problemi. Glede na odgovore, se je kar enajst (92\%) RRA srečevalo s problemom nezadostnih finančnih virov. Ključni problem pa so bili tudi birokratski postopki, saj je imelo z njimi težave sedem RRA $(58 \%)$. Kot tretji najpogostejši problem se je izkazalo nezadostno sodelovanje državnih institucij (štiri RRA). Najmanjši problem pa so RRA videle v tem, da bi uporabniki slabo poznali delovanje agencij (samo dve RRA). 
Bačlija, Gologranc, Kukovič

Institucionalna kapaciteta regionalnih razvojnih agencij v Sloveniji?

Tabela 3: Financiranje RRA

\begin{tabular}{|c|c|c|c|c|c|}
\hline RRA & $\begin{array}{l}\text { sredstva } \\
\text { ustanovi- } \\
\text { teljev }\end{array}$ & $\begin{array}{l}\text { sredstva za } \\
\text { izvajanje projek- } \\
\text { tov } \vee \text { okviru } \\
\text { programov } \\
\text { državnih razvoj- } \\
\text { nih spodbud }\end{array}$ & $\begin{array}{l}\text { sredstva } \\
\text { mednarodnih } \\
\text { pomoči }\end{array}$ & $\begin{array}{l}\text { sredstva } \\
\text { zainteresi- } \\
\text { ranih } \\
\text { naročnikov }\end{array}$ & drugo \\
\hline RRA Celje & $30 \%$ & $40 \%$ & $20 \%$ & $10 \%$ & $0 \%$ \\
\hline RRA Koroška & $42 \%$ & $40 \%$ & $0 \%$ & $0 \%$ & $18 \%$ \\
\hline RRA Gorenjske & $20 \%$ & $10 \%$ & $5 \%$ & $5 \%$ & $60 \%$ \\
\hline RRA Mura & $6 \%$ & $52,5 \%$ & $39 \%$ & $2,5 \%$ & $0 \%$ \\
\hline $\begin{array}{l}\text { RRA Ljubljanske } \\
\text { urbane regije }\end{array}$ & $80 \%$ & $3 \%$ & $0 \%$ & $17 \%$ & $0 \%$ \\
\hline RRC Koper & $1 \%$ & $17 \%$ & $0 \%$ & $0 \%$ & $82 \%$ \\
\hline $\begin{array}{l}\text { RC za razvoj } \\
\text { Zasavje }\end{array}$ & $0 \%$ & $70 \%$ & $0 \%$ & $30 \%$ & $0 \%$ \\
\hline $\begin{array}{l}\text { Posoški razvojni } \\
\text { center }\end{array}$ & $8 \%$ & $15 \%$ & $50 \%$ & $20 \%$ & $7 \%$ \\
\hline RRA Posavje & $27 \%$ & $57 \%$ & $0 \%$ & $0 \%$ & $16 \%$ \\
\hline $\begin{array}{l}\text { RRA Notranjsko- } \\
\text { kraške regije }\end{array}$ & $0 \%$ & $0 \%$ & $0 \%$ & $20 \%$ & $80 \%$ \\
\hline
\end{tabular}

Vir: Raziskava $v$ okviru predmeta Primerjalni federalizem in regionalizem na Fakulteti za družbene vede; $\mathrm{N}=10$ 
Bačlija, Gologranc, Kukovič

Institucionalna kapaciteta regionalnih

razvojnih agencij v Sloveniji?

\section{Zaključek ali kakšna bo usoda agencij po uvedbi pokrajin?}

Glede na teoretična izhodišča o primernosti regionalizacije (decentralizacije) Slovenije (glej Dunn in Wetzel, 2000) se avtorice tega članka bolj nagibamo v prid "nenasilni« regionalizaciji oziroma k regionalizaciji brez ustvarjene regionalne ravni. Menimo da je mogoče s pomočjo do sedaj obstoječih nosilcev regionalnih razvojnih potencialov (med njimi RRA) s časoma prav tako (če ne celo bolje) doseči skladen regionalen razvoj, ki temelji na sodobnih načelih podjetništva in inovacij. Kakorkoli že, oblike in vloga pokrajin $v$ Sloveniji so bolj ali manj znane in določene. Na tem mestu naj poudarimo, da je bil potencial RRA zanemarjen tudi pri oblikovanju pokrajinske zakonodaje, kar pomeni, da s svojo ekspertizo in doživljanjem regionalnega razvoja $v$ večletni praksi niso sodelovale pri oblikovanju področne zakonodaje. Ob široki razpravi o številu oziroma obsegu pokrajin ter ob dvopolnih mnenjih o tem ali naj bodo pokrajine "dvoživke" ali ne, se je pozabilo na največjo in najbolj zahtevno nalogo pokrajin, to je na njihovo vlogo pri regionalnem strateškem razvoju. Pred uvedbo druge ravni lokalne samouprave bi bilo treba natančneje ovrednotiti dosedanje delovanje nosilcev regionalnega razvoja ter upoštevati njihove izkušnje pri oblikovanju vsebine pokrajin.

Pozitivno je, da je zakonodajalec vendarle predvidel nekakšno vlogo (vsaj nekaterih) RRA, ki naj bi se obdržale $v$ regijah, pri čemer je po eni strani omogočil kontinuiteto znanj, ki so se akumulirala $\vee$ RRA, po drugi strani pa je ravno z opcijo popolnega umika oziroma razkroja nekaterih RRA omogočil, da se oblikujejo drugi nosilci regionalnega razvoja, kjer pa se dopušča možnost političnega kadrovanja. Če se občine do sedaj niso povezovale z RRA oziroma so do sodelovanja z njimi kazale bolj malo zanimanja, se lahko vprašamo, kakšni bodo po novem motivi občin, da sodelujejo pri razvijanju regionalne strategije. Po vsej verjetnosti bo šlo za lokalne politične motive, kar bo regionalni razvojni strategiji dalo nekakšno legitimnost, morda ravno na račun strokovnosti. 


\section{Bačlija, Gologranc, Kukovič \\ Institucionalna kapaciteta regionalnih razvojnih agencij v Sloveniji?}

Irena Bačlija je asistentka (habilitirana na področju politologije) in doktorska študentka na Fakulteti za družbene vede ter mlada raziskovalka na Centru za politološko raziskovanje. Njeno primarno področje raziskovanja je lokalna samouprava, še posebej lokalno upravljanje, sub-lokalne entitete, urbana decentralizacija in tudi regionalizem. Poleg tega, da je sodelovala pri večih ciljno-raziskovalnih projektih znotraj Centra za politološko raziskovanje pa je tudi soavtorica dveh znanstvenih monografij ter avtorica večih znanstvenih člankov, ko so bili objavljeni tako doma, kot v tujini.

Gaja Gologranc je študentka na dodiplomskem študiju analize politik in javne uprave na Fakulteti za družbene vede in demonstratorka pri predmetu Uvod v javno upravo.

Simona Kukovič je študentka na dodiplomskem študiju analize politik in javne uprave na Fakulteti za družbene vede in demonstratorka pri predmetu Uvod $v$ javno upravo.

\section{Literatura in viri}

- (1999). Zakon o spodbujanju skladnega regionalnega razvoja. Uradni list RS, št. 60/99ZSRR in 56/03.

- (2000). Pravilnik o organizaciji in pogojih za opravljanje nalog RRA. Uradni list RS, št. $52 / 2000$ in $110 / 2004$.

- (2004). Pravilnik o organizaciji in pogojih za opravljanje nalog regionalne razvojne agencije. Uradni list RS, št. 110/2004.

- (2005). Pravilnik o subjektih spodbujanja razvoja na regionalni ravni. Uradni list RS, št. 93/05.

- (2005). Zakon o spodbujanju skladnega regionalnega razvoja. Uradni list RS, št. 93/2005ZSRR-1.

- (2006). Pravilnik o subjektih spodbujanja razvoja na regionalni ravni. Uradni list RS, št. 103/2006.

- (2007). Predlog zakona o prenosu nalog v pristojnost pokrajin - predlog za obravnavo. Služba Vlade Republike Slovenije za lokalno samoupravo in regionalno politiko.

- Dunn, J., Wetzel, D. (2000). Fiscal decentralization in Former Socialist Economies: Progress and Prospects. Priloga k seminarju v okviru Svetovne banke (World Bank): Intergo- 
Bačlija, Gologranc, Kukovič

Institucionalna kapaciteta regionalnih

razvojnih agencij v Sloveniji?

vernmental Fiscal Relations and Local Financial Management. Budimpešta, 10. - 15. maja.

- Gulič et al (Ed.). (1993). Regionalni razvoj in regionalizacija Slovenije: analiza stanja in predlogi za spremembe - 3.faza. Ljubljana, Urbanistični inštitut RS: Inštitut za ekonomska raziskovanja.

- Haček, M. (2002): „Regionalizacija Slovenije ob vstopanju in po vstopu v Evropsko Unijo ". Raziskava v okviru programa raziskovalnih štipendij Mirovnega inštituta, Ljubljana.

- Haček, M., Brezovšek, M. in Bačlija I. (2008). Upravljavska sposobnost in koalicijsko povezovanje $v$ slovenskih občinah. Ljubljana: Fakulteta za družbene vede.

- Pečar, J. (2002). Regionalni vidiki Razvoja Slovenije (in poslovanje gospodarskih družb v letu 2000).Ljubljana: Urad za makroekonomske analize in razvoj.

- Ribičič, C. (Ed.). (1998). Regionalizem v Sloveniji. Ljubljana: ČZ Uradni list.

- Šmidovnik, J. (1991). Lokalna samouprava, centralizem in regionalizem. Teorija in praksa (7), 874 .

- Šmidovnik, J. (1995). Lokalna samouprava. Ljubljana: Cankarjeva založba.

- $\quad$ Špes, M. (Ed.). (2000). Regionalni razvoj v Sloveniji. Ljubljana: Inštitut za geografijo.

- Vlaj, S. (1998). Lokalna samouprava. Občine in pokrajine. Ljubljana: Fakulteta za družbene vede.

- Vlaj, S. (2001). Pokrajine - raven med državo in občinami. Javna uprava (4), 535-565.

- Zajc, D. (Ed.). (2001). Slovenska država - ob deseti obletnici. Ljubljana: Založba FDV. 


\section{SUMMARY}

\section{THE INSTITUTIONAL CAPACITY OF REGIONAL DEVELOPIMENT AGENCIES}

Slovenia is currently in the process of establishing a second level of local self-government, namely, regions. The true urgency of establishing this regional level is debatable; however, the regionalisation itself is no longer in question. The only unanswered question that remains is when they will actually be established. In the intermediate period between the establishment of municipalities (1994) and the establishment of regions, Slovenia has sought to overcome the deficit of the second level of local self-government with many mechanisms (institutions) including the National Agency for Regional Development and, within that, the regional development agencies which form the main focus of this article.

The authors argue that the regional development agencies have been a vital link in recognising common interests in a wider local territory and therefore their experience is crucial for the future understanding of regional competencies. According to this, research about the institutional capacity of regional development agencies was conducted. Based on the results, the authors explain the role the regional development agencies will play after the establishment of regions and answer the question of whether their personnel and infrastructure potential will be broken up in the direction of the regional administrations.

As a concept, regionalisation is institutional process and should not be equated with regionalism, which is a political and ideological movement. There are three different types of regionalisation: (1) regionalisation without a regional level being created; (2) regional decentralisation; and (3) political regionalisation (institutional regionalism). Debate concerning regionalisation in Slovenia is linked to the principle of subsidiarity, harmonious regional development and European trends of regionalisation in general. Harmonious regional development in Slovenia has its roots in 1971 when the first legislation connected to it was accepted. However, the last big change occurred in 1999, when, for the purpose of encouraging the development of demographically weakened areas the Act on the Encouragement of Harmonious Regional Development was accepted. Due to frequent criticism (linked especially to provisions on the organisation and implementation of regional policy), the National Assembly passed a new Act on the Encouragement of Harmonious Regional Development 
Bačlija, Gologranc, Kukovič

Institucionalna kapaciteta regionalnih

razvojnih agencij v Sloveniji?

(Official Gazette, Nos. 93/2005 and 127/2006). The former act was amended to such an extent that it was no longer possible to make amendments to the act but it became necessary to draft a new act. For the purpose of our article, the most important change is the one that refers to the implementation and final decision-making on regional policy. The new act brought about major changes concerning the organisation of regional development planning and which is the body that prepares and accepts a development plan. It is obvious that decision-making will be transferred (to a greater extent) to regional political actors, that is to the Association of Municipalities (the tasks of the Association of Municipalities will be to accept the regional development programme and confirm the implementation plan of the regional development programme).

To establish the institutional capacity of regional development agencies and their influence on development activities we conducted research in 2007. The findings include some basic facts: there are 150 people employed in 12 registered regional development agencies; however, there are considerable differences in the number of employees between individual regional development agencies. For example, the Zasavje Regional Development Centre has 23 employees, while the Posavje Regional Development Agency and Notranjsko-kraške Regional Development Agency only have seven employees. It can also be assumed that the number of the founders (municipalities and private companies) does not precondition the number of employees in an individual regional development agency. Employees are experts in different fields (from jurists, political scientists, economists, building contractors etc.) and the level of education of the employees also varies. Most employees (58\%) have a college degree, followed by employees with a higher education (15\%), employees with a high-school education (13\%) and those with a master's degree or $\mathrm{PhD}(13 \%)$. Therefore, the regional development agencies employ highly educated staff and obviously expertise from different fields is needed. We should mention that the regional development agencies cover many different areas and therefore contribute to the more efficient and professional activity of the regional development agencies. For these reasons, we may argue that the personnel potential represents the driving force of the regional development agencies. In addition, we also wondered if the regional development agencies were having problems with a lack of qualified staff. In five regional development agencies they did not detect a personnel deficit; however, lawyers are needed in two regional development agencies and economists in one regional development agency. The regional development agencies also pointed out that they require flexible and multidisciplinary staff with leadership and organisational skills. We can 
Bačlija, Gologranc, Kukovič

Institucionalna kapaciteta regionalnih

razvojnih agencij v Sloveniji?

conclude that, besides their professional expertise, the staff must have knowledge about the activity on the level of the entire regional development agency. This could therefore be an unambiguous indicator for future regional administration which, in some cases, will take over the tasks of the regional development agencies.

Another component of the institutional capacity of the regional development agencies is their co-operation with other institutions (on the European, national and regional levels). We may conclude that the regional development agencies co-operate with different institutions. All 12 regional development agencies namely co-operate with Slovenian administrative and political institutions and with the municipalities. Cooperation with private companies and public agencies follows, as well as co-operation with European institutions. Interactions are already established between the municipalities and the regional development agencies; however, they only co-operate on individual projects that the municipalities are familiar with. In another study (Faculty of Social Sciences, 2007), part of which is covered in the article, the municipalities emphasised poor knowledge of the activities of the regional development agencies. This could mean that there is a lack of interest by the municipalities about obtaining information concerning the activities of the regional development agencies or that the regional development agencies are not recognisable enough in their local environment. On the other hand, the regional development agencies do not perceive that the municipalities have poor knowledge of their activities. According to the data we obtained, we wonder: (1) whether the regional development agencies are not aware of this problem; (2) they do not have an interest in co-operation; or (3) they are not stressing it, because they are heavily engaged in gaining financial resources and other obstacles like complicated bureaucratic procedures. Another component of the capacity of the regional development agencies are the institutional deficits of the regional development agencies. The employees believe that the regional development agencies encounter various problems quite often. According to the answers, 11 regional development agencies have a problem of insufficient financial resources. As many as seven regional development agencies have problems with bureaucratic procedures and insufficient co-operation among state institutions.

We should also mention the financing of the regional development agencies, which is another component of their institutional capacity. The regional development agencies are financed by their founders, from the national budget, through funds from projects, international aid and from funds of interested clients. We can conclude that the amounts of resources gained strongly differ between individual regional development agencies. 
Bačlija, Gologranc, Kukovič

Institucionalna kapaciteta regionalnih

razvojnih agencij v Sloveniji?

Considering that regions will be established and that eight regional development agencies are being financed by their founders, we might question how much financing of the founders the regional development agencies will receive after they are established.

Considering the theoretical starting points about the suitability of regionalisation on Slovenian territory, we lean towards a "non-violent" regionalisation or regionalisation without a regional level being created. We believe it is possible, with the help of the regional development actors existing so far (including the regional development agencies), with time to equally (if not even better) achieve harmonious regional development based on modern principles of business and innovations. The forms and role of regions in Slovenia are already more or less known and defined. Next to the extensive debate about the number of regions and bipolar opinions about whether the regions should act as a deconcentrated unit for the state administration as well as the second level of local-self-government or not, the largest and most demanding role of the regions has been forgotten, namely their role as a regional strategic developer.

It is necessary to (more carefully) evaluate the previous activities of actors for regional development before implementation of the second level of local self-government takes place. It must be said that the legislator nevertheless anticipated a certain role for the regional development agencies; they would manage to remain as regional actors. With this, on one hand the legislator enabled the continuity of knowledge (as accumulated in the regional development agencies). But, on the other hand, the legislator allowed the formation of other actors of regional development whereby the possibility of politically-influenced staffing is being allowed. If so far the municipalities have not been co-operating with the regional development agencies or shown little interest in them, we may question what will be the new motives of the municipalities to co-operate when it comes to developing regional strategies. Most likely what will come into play will be local political motives which are not usually backed up by expert opinions, but will at least give the regional developmental strategy a certain political legitimacy.

\section{Opravičilo}

V reviji Uprava letnik VI, št. 4, december 2008 je pri članku z naslovom »Razlaga pravnih pravil s pomočjo propozicijske logike - primer družinskih prejemkov“ prišlo do napačnega poimenovanja vrstnega reda avtorjev. Iz objavljenega je bilo razbrati, da je prvi avtor Iztok Rakar. Pravilni zapis je, da je prvi avtor Domen Cukjati, drugi pa Iztok Rakar. Avtorjema se opravičujemo za nastalo napako.

Uredništvo revije 